\title{
Spatial and Temporal Hydrochemical Variation of a Third Order River Network in a Quasi Pristine Coastal Watershed, at Southern Bahia, Brazil
}

\author{
ELLY R.S. DE SOUZA ${ }^{1}$ and FRANCISCO C.F. DE PAULA ${ }^{2}$ \\ ${ }^{1}$ Programa de Pós-Graduação em Sistemas Aquáticos Tropicais, \\ Universidade Estadual de Santa Cruz, Rodovia Ilhéus/Itabuna Km 16, 45662-900 Ilhéus, BA, Brasil \\ ${ }^{2}$ Universidade Estadual de Santa Cruz, Departamento de Ciências \\ Agrárias e Ambientais, Rodovia Ilhéus/Itabuna Km 16, 45662-900 Ilhéus, BA, Brasil \\ Manuscript received on February 8, 2011; accepted for publication on October 5, 2012
}

\begin{abstract}
Rio da Serra watershed presents well preserved fragments of rain forest at the headwaters and small farms at middle and final stretches. These features allowed the study of fluvial hydrochemistry, under quasi pristine conditions. Sampling stations were established in order to represent the basin, and visited during dry, intermediate and wet periods. Obtained results are: temperature $\left(22.1-28.6{ }^{\circ} \mathrm{C}\right)$; electric conductivity $(34-52 \mu \mathrm{S} / \mathrm{cm})$; dissolved oxygen $(35-110 \%) ; \mathrm{pH}(3.8-7.7)$; total suspended solids $(1.1-20 \mathrm{mg} / \mathrm{L})$; chlorophyll $(1.0-9.2 \mu \mathrm{g} / \mathrm{L})$; total $\mathrm{N}(74-580 \mu \mathrm{mol} / \mathrm{L})$; particulate $\mathrm{N}(60-550 \mu \mathrm{mol} / \mathrm{L}) ; \mathrm{N}^{-N_{3}}(0.1-9.3$ $\mu \mathrm{mol} / \mathrm{L})$; dissolved organic $\mathrm{N}(4-70 \mu \mathrm{mol} / \mathrm{L})$; total phosphorous $(5.3-47 \mu \mathrm{mol} / \mathrm{L})$; particulate $\mathrm{P}(4.4-59$ $\mu \mathrm{mol} / \mathrm{L}) ; \mathrm{P}_{-} \mathrm{PO}_{4}(0.1-0.7 \mu \mathrm{mol} / \mathrm{L})$; dissolved organic $\mathrm{P}(0.01-2.0 \mu \mathrm{mol} / \mathrm{L})$; silicate $(30-90 \mu \mathrm{mol} / \mathrm{L})$; fecal coliforms $(80-700 \mathrm{CFU} / 100 \mathrm{~mL})$. In seasonal terms dissolved oxygen, electric conductivity, nitrate and silicate concentrations were higher during the dry, whereas TSS was higher during the wet period. Seasonal differences of dissolved oxygen, temperature, $\mathrm{pH}$ and nitrate were also detected near wetlands areas. Along the basin results showed a distinction between headwaters and other sections, revealing a control of fluvial hydrochemistry by the preserved area, mostly for the dissolved organic $\mathrm{N}$ and $\mathrm{P}$ species and phosphate.
\end{abstract}

Key words: Rivers ecology, dissolved nutrients, biological reserve, wetlands.

\section{INTRODUCTION}

The fluvial systems form indissociable and interdependent units with their respective watershed (Hynes 1975, Petts 2000). The limnological characteristics of a water basin are the result of the properties of the present ecosystems, allied to physiographic factors such as lithology, relief and vegetation, besides population density and, still, climatic factors and seasonality (Camargo et al. 1996).

Correspondence to: Francisco Carlos Fernandes de Paula

E-mail:depaula@uesc.br
Weathering of rocks, important determining factor of the fluvial chemistry (Hynes 1975, Allan 1995), together with the rainfall and evaporation (Gibbs 1970) control the salinity of water bodies, while the seasonal wet and dry propitiate a dynamic flow of nutrients and organic matter, determining characteristics of physical, chemical and biological factors differentiated between these periods (Junk et al. 1989). The lotic systems can be comprehended as structured in a predictable way at length of a body continuum, from the 
source to the mouth and with different properties in its three phases: superior, medium and final patch (Vannote et al. 1980) and according with the serial discontinuity concept from Ward and Stanford (1983), natural or anthropic factors, such as wets, dams or contaminant wasting, can cause alterations in this fluvial continuum.

Among the anthropogenic actions, deforestation, non-treated domestic sewage and urban and agiculture wastes are the principal modifying activities of the aquatic environment (Smith and Petrere Jr 2000, Marques et al. 2003, Martinelli et al. 2002), with conspicuous presence in Brazilian watersheds. These actions are responsible for profound modifications in the structure and function of ecosystems (Smith and Petrere Jr 2000, Marques et al. 2003, Krusche et al. 2005, Lorandi and Cançado 2005, Martinelli et al. 2002, Esteves 1998), altering, for example, the size of nutrient pools, the flows between pools and nutrients speciation.

The Southern region of Bahia State concentrates the most important remnants of tropical rainforest of the Brazilian Northeast (Araújo et al. 1998). This region is recognized by its high biodiversity and rates of endemism (Wayt Thomas et al. 1998, MAB/UNESCO 1972) and stated as one of the five principal hotspots for the conservation on the planet (Meyers et al. 2000). Anthropogenic activities have reduced to less than $8 \%$ of the original forest area (SOS MATA ATLÂNTICA / INPE 2009) and these remaining forests are still under pressure. Regionally the principal impacts refer to the removal of the original vegetation and low indexes of basic sewage services coverage in the cities.

Pristine areas offer the opportunity to follow up the natural functioning of the fluvial processes (DePaula and Mozeto 2001, Marques et al. 2003). They permit to define the reference levels, or background, for nutrients, coliforms, or other elements, useful to subsidize actions aiming the restoration of impacted environments. The study of watersheds free from major human interventions, contributes to the comprehension of the natural processes before the anthropogenic actions interfere in their complexity (Lowe-McConnell 1987).

The principal objective of this work is to characterize the variation of the hydrochemistry in a watershed of a tropical rainforest, at different phases of the hydrograph, whose headwaters region presents an excellent state of preservation and different occupation degrees, in the medium and final patches.

\section{MATERIALS AND METHODS}

STUDY AREA

The drainage basin of the Rio da Serra is located at the Southern region of State of Bahia (Fig. 1), possessing typical environments from the Atlantic Rainforest Domain. Its headwaters are contained in the Una Biological Reserve (REBIO de Una; ID 48 at WDPA), grading its excellent preservation state, since this Conservation Unit category is the most restrictive in relation to the general state of its landscapes (Brasil 2000). The medium patch is characterized by small properties which fulfill agricultural activities, husbandry and wood extraction and the final patch is composed of restinga and mangrove ecosystems. There are, in all the extension of the draining basin, no significant population nucleus such as cities, existing just some isolated housings.

The region presents the Af climate type in the Köpen classification, without a defined dry season, with annual precipitation close to $2,000 \mathrm{~mm}$. The medium temperature stays around $24^{\circ} \mathrm{C}$ with minima never lower than $18^{\circ} \mathrm{C}$. The geological substrate is formed by two stratigraphycal units: the Jequié Complex in the south of Bahia, which presents rocks of granulite facies, represented principally by gneisses and the Barreiras Formation, composed by unconsolidated sediments, with a lithological constitution predominantly of quartz phenoclasts besides of granulite gravel (Brasil 1976). 


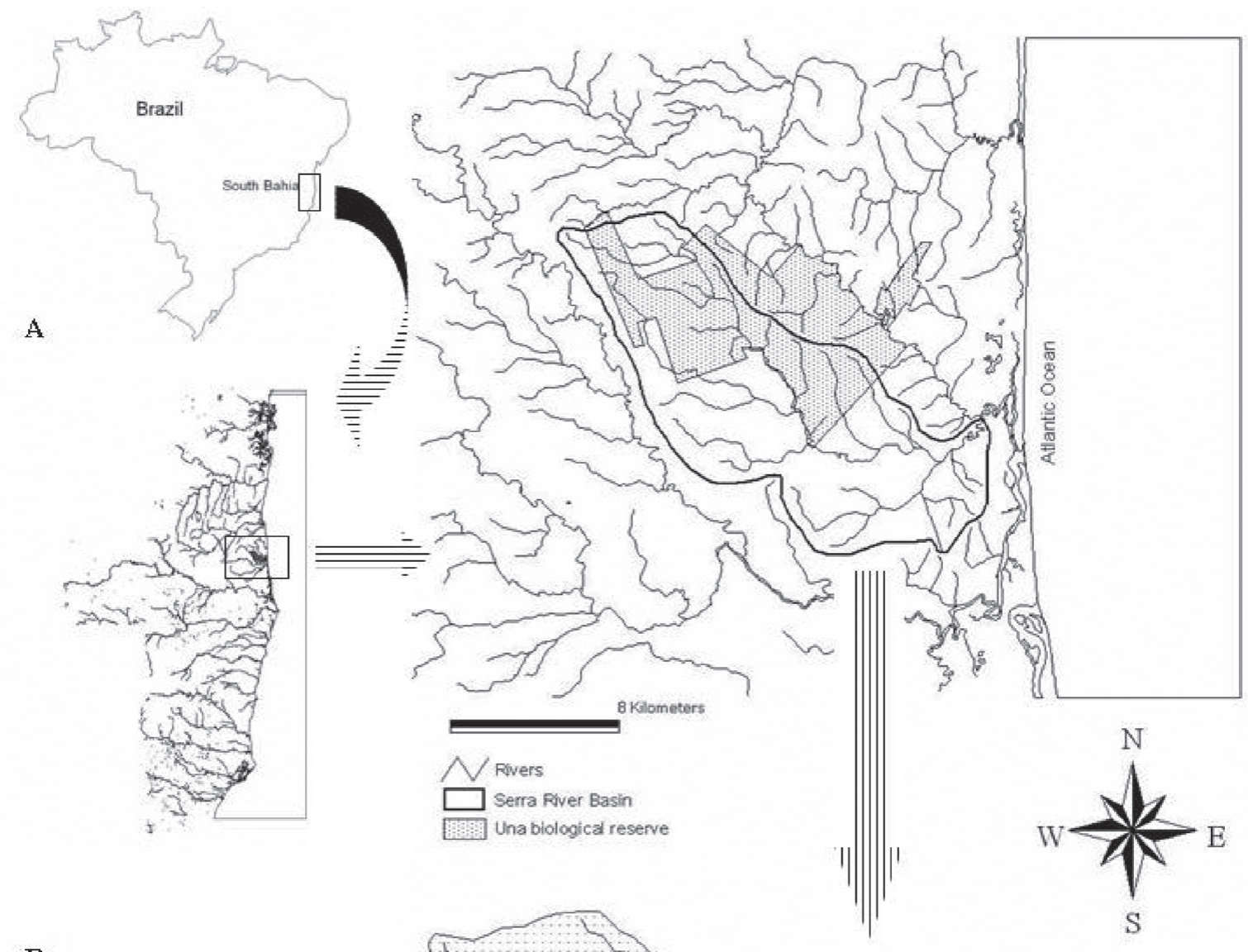

B
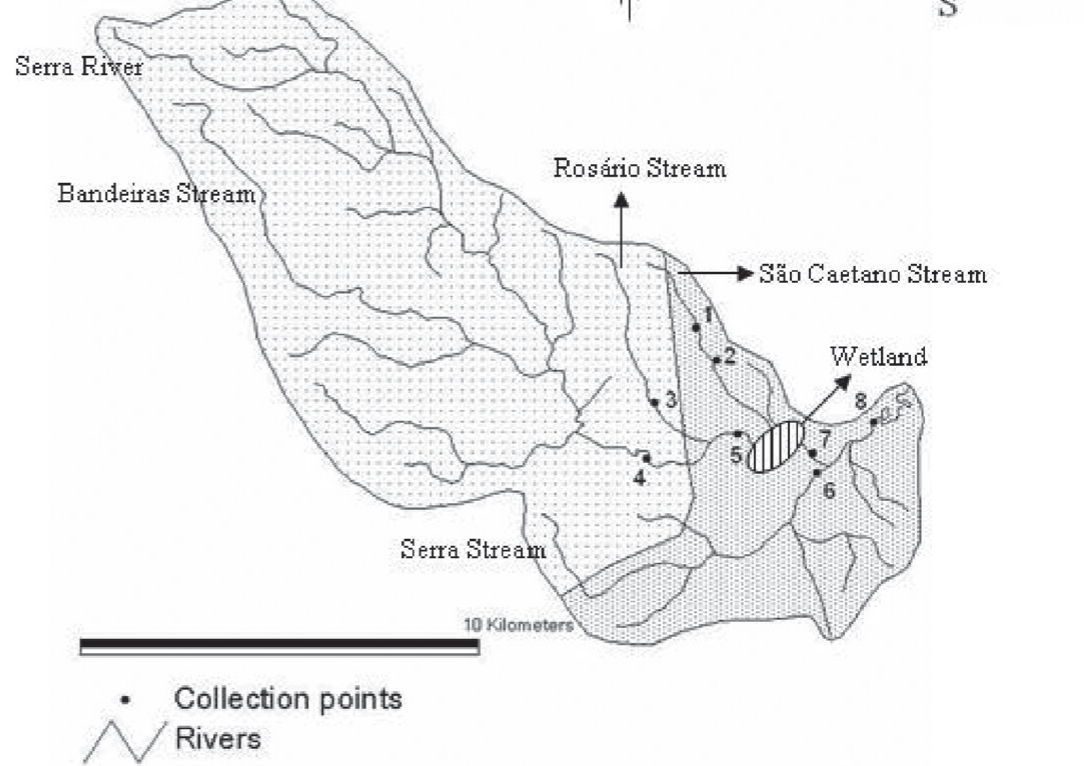

Complexo Jequié

Formação Barreiras

Figure 1 - Map of Rio da Serra Basin. (A) Location of the basin with highlight for the Una Biological Reserve. (B) Hydrography of the basin with the location of the eight stations, and the distribution of the two present geological types: the Jequié Complex at west and the Barreiras Formation at east. Modified from Landau et al. (2003). 


\section{SAMPLING DESIGN}

Six sampling campaigns were performed between November 2007 and May 2008 in eight stations (Table I), and sampling analysis accomplished well established protocols (Table II). Some analyses were performed in duplicate to evaluate the analytical precision of the measurement. Differences between duplicate samples were, in general, lower than $2.5 \%$ and never higher than $8 \%$. The results were initially submitted to descriptive statistic and subsequently to parametric statistic. They were submitted to normality test, using the Kolmogorov-Smirnov or Lillefors test for the application of the parametrical analyses, with assistance of BioEstat software 4.0 (Zar 1999). For the analysis of significant differences among stations and the sample campaigns, a variance analysis was utilized (ANOVA 2 criteria). To test significant differences among averages, a "t" Student test was utlized. The analysis of association among stations and seasonality was done by the Principal Components (PCA), using the PAST software (Hammer et al. 2001).

For the analysis of land uses in the study area, a LANDSAT - TM 2005 image was utilized in spectral bands 2, 3 and 4, which was processed with the assistance of IDRISE ANDES software. Based on the treatment, areas covered by vegetation can be differentiated from the agro-pastoral landscapes which present undergrowth or exposed soil. Areas of deeper vegetal coverage and areas with vegetal coverage in succession stage can also be verified. The treated image was then processed by ArcView software, for the delimitation of the basin, classification of the soil occupation and calculation of the respective areas.

\section{RESULTS AND DISCUSSION}

The used SIG techniques allowed to define the Rio da Serra Basin with an area of $158 \mathrm{~km}^{2}$ (third order drainage), being $28 \%$ of this total covered by vegetation in excellent conservation state,

TABLE I

Description of the sampling stations with percentages of their collection areas and maximum river width.

\begin{tabular}{cccc}
\hline Stations & Collection area (\%) & Width $(\mathrm{m})$ & Area description \\
\hline 1 & 2 & 1.5 & Primary Forest \\
\hline 2 & 3 & 2.9 & Primary Forest \\
\hline 3 & 4 & 2.7 & Primary Forest \\
\hline 4 & 63 & 6.0 & $\begin{array}{c}\text { Rio da Serra, after it receives the waters of the } \\
\text { Bandeira Stream. These rivers traverse an area } \\
\text { recently incorporated to the Biological Reserve and are } \\
\text { representative of a previous agricultural area, which is } \\
\text { in a phase of ecological succession. }\end{array}$ \\
\hline 5 & 70 & 5.5 & $\begin{array}{c}\text { Rio da Serra zone, downstream point 4, in an } \\
\text { agricultural area. }\end{array}$ \\
\hline 7 & 19 & 3.0 & $\begin{array}{c}\text { This sub-basin has large areas of agriculture and } \\
\text { pasture. At this station, submersed and floating aquatic } \\
\text { macrophytes occur and water flow is slow. This station } \\
\text { is located in the neighborhood of a marginal lagoon. }\end{array}$ \\
\hline 8 & 77 & 6.0 & $\begin{array}{c}\text { Rio da Serra zone, downstream point 5, after the river } \\
\text { traverses a large wetland }\end{array}$ \\
\hline
\end{tabular}


characterized by the stations 1,2 and 3 . Another $44 \%$ of the basin is covered by forests in ecological succession stage, principally represented by point 4. At last, $28 \%$ of the basin presents some level of human occupation with agro-pastoral activities, where the other points are located (Fig. 2).

TABLE II

Methods used in the analyses of the studied variables.

\begin{tabular}{cc}
\hline VARIABLES & METHODS \\
\hline $\begin{array}{c}\text { Dissolved oxygen; } \\
\text { temperature; } \mathrm{pH} \text {; Electric } \\
\text { Conductivity }\end{array}$ & $\begin{array}{c}\text { Portable multi parameter } \\
\text { (WTW 530i). }\end{array}$ \\
\hline TSS & Strickland and Parsons \\
$(1972)$
\end{tabular}

Total and particulate $\mathrm{N}$ and $\mathrm{P}$; dissolved organic $\mathrm{N}$ and $\mathrm{P}$; nitrate, nitrite and

Grasshoff et al. (1983)

ammonia; phosphate

\begin{tabular}{cc}
\hline Silicate & Carmouze (1994) \\
\hline Chlorophyll & Parsons et al. (1984) \\
\hline Fecal Coliforms & APHA (1995) \\
\hline
\end{tabular}

The rainfall data interpretations, based on the total precipitation during seven, fifteen and thirty days previous of the sampling (Fig. 3), allowed to classify the campaigns 1 and 6 as representative of the dry period, campaigns 2 and 4 representative of the wet periods and campaigns 3 and 5 typifying an intermediate period.

Figure 4 shows the results of the physicalchemical variables, TSS and chlorophyll, obtained in each sampling point in the six performed campaigns. The fluvial physical-chemical results of the Rio da Serra basin are similar to the results obtained in other basins of the Brazilian Atlantic Rainforest (DePaula and Mozeto Jr 2001, Marques et al. 2003, Necchi Jr et al. 2000, Sator et al. 2007). Due to the normally elevated precipitation, the constant leaching of the profile results in low salinity waters, from 2 to $90 \mu \mathrm{S} / \mathrm{cm}$. Also the obtained $\mathrm{pH}$, DO and TSS results are in the characteristic range of the basins of the Domain, with slightly acid waters (pH from 5 to 7 ), well oxygenated (50 to $120 \%$

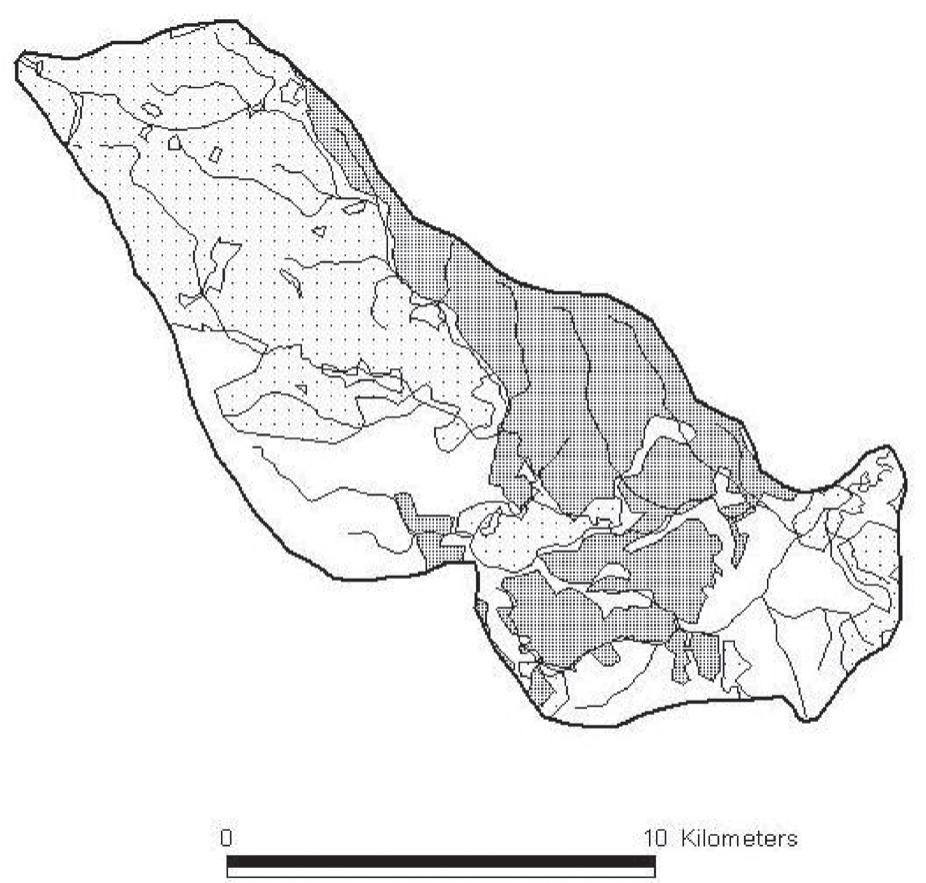

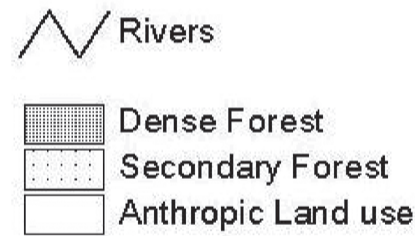

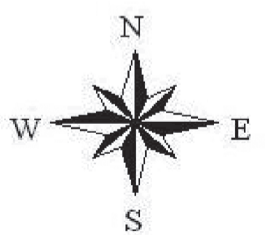

Figure 2 - Land cover at Rio da Serra Basin. Obtained from LandSat images mapped with ArcView software. Black dots resemble sampling stations as Figure 1. 


\section{Accumulated precipitation}

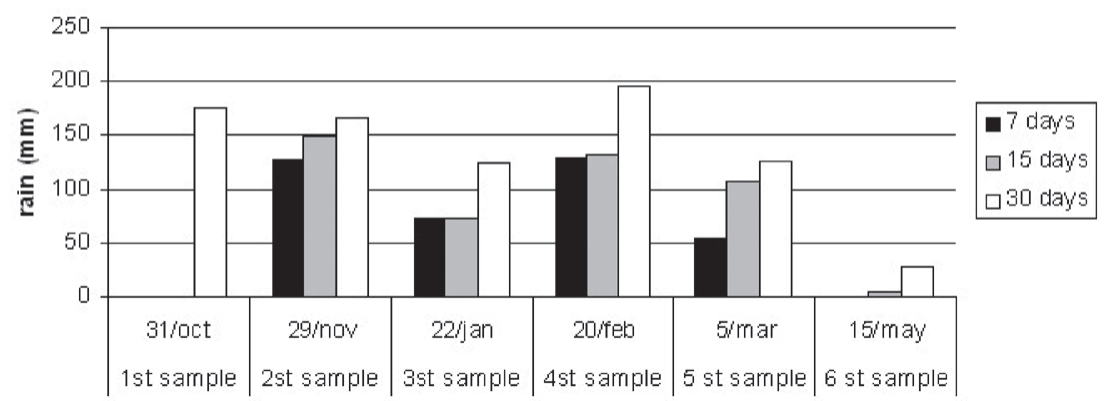

Figure 3 - Accumulated rainfall in the last 7, 15 and 30 days previous to each sampling campaign. Data from: Setor de Climatologia CEPLAC/CEPEC (Ilhéus-BA).

oxygen saturation) and of low turbidity (TSS from 1.0 to $20 \mathrm{mg} / \mathrm{L}$ ). Variability of these parameters depends on the major or minor preservation state of the original forest cover and the presence of wastes from agriculture or urban effluents, without previous treatment.

Chlorophyll values fits very well to the River Continuum Concept (Vanotte 1980), presenting an increase downward the basin, varying from 1.0 to $5.0 \mu \mathrm{g} / \mathrm{L}$, at the headwaters, from 1.4 to $7.5 \mu \mathrm{g} / \mathrm{L}$ and from 1.6 to $9.2 \mu \mathrm{g} / \mathrm{L}$ in the middle and lower portions of the watershed, respectively. As the river becomes wider and mineralization of organic debris modify the speciation of nutrients, that became more available as dissolved forms, the primary production could experience such a detected increase. Total dissolved $\mathrm{P}$ minimum to maximum concentrations, for example, present the same behavior, ranging from 0.2 to $1.7 \mu \mathrm{M}$ in headwaters, from 0.3 to $2.1 \mu \mathrm{M}$ at the middle and 0.2 to $2.4 \mu \mathrm{M}$ at the lower stretch.

Both $\mathrm{N}$ and $\mathrm{P}$ presented a predominance of the particulate upon the dissolved fraction, in average, $90 \%$ of the TN and $95 \%$ for the TP. This speciation of nitrogen and phosphorus is maintained till the final patch of the basin, where $91 \%$ of the TN and $97 \%$ of the TP that arrive at the estuary are in particulate form (Fig. 5). Such speciation for these elements is usually found, principally in lower order rivers (Horne and Goldman 1994, Wetzel 1993).
The TN values oscillate from 74 to 581 $\mu \mathrm{M}$ and the TP from 5 to $47 \mu \mathrm{M}$ (Fig. 6). In the dissolved fraction, the organic form of total dissolved nitrogen (TDN) appeared in larger percentual at all the stations, completing a total of $92 \%$ at the headwater points, reducing to $79 \%$ in the medium and final patches. For the phosphorus, the organic form predominated upon the inorganic form in the medium and final patches of the basin, where around of $84 \%$ of the TDP was in organic form, while at the headwater points there existed a predominance of the inorganic form, completing a total of $56 \%$ of the TDP. This difference between $\mathrm{N}$ and $\mathrm{P}$ is justified first by the role played by the geogenic contribution of the phosphorus cycling in superficial environment, being the passage to the biotic reservoir occurring more downstream the hydrographical basins, as determined by the concept of river continuum. The second aspect refers to the higher nitrogen concentration in more labile organic molecules (ex. proteins), which are promptly disponibilized for the hydric bodies, even in the headwater regions.

In relation to the spatial gradient of the basin, the ANOVA variance analysis points out differences among the points and collection ( $p$ $<0.05$ ) and the TUKEY test revealed that the temperature values, $\mathrm{pH}$, TSS, chlorophyll and nitrate are significantly minor at the headwater 


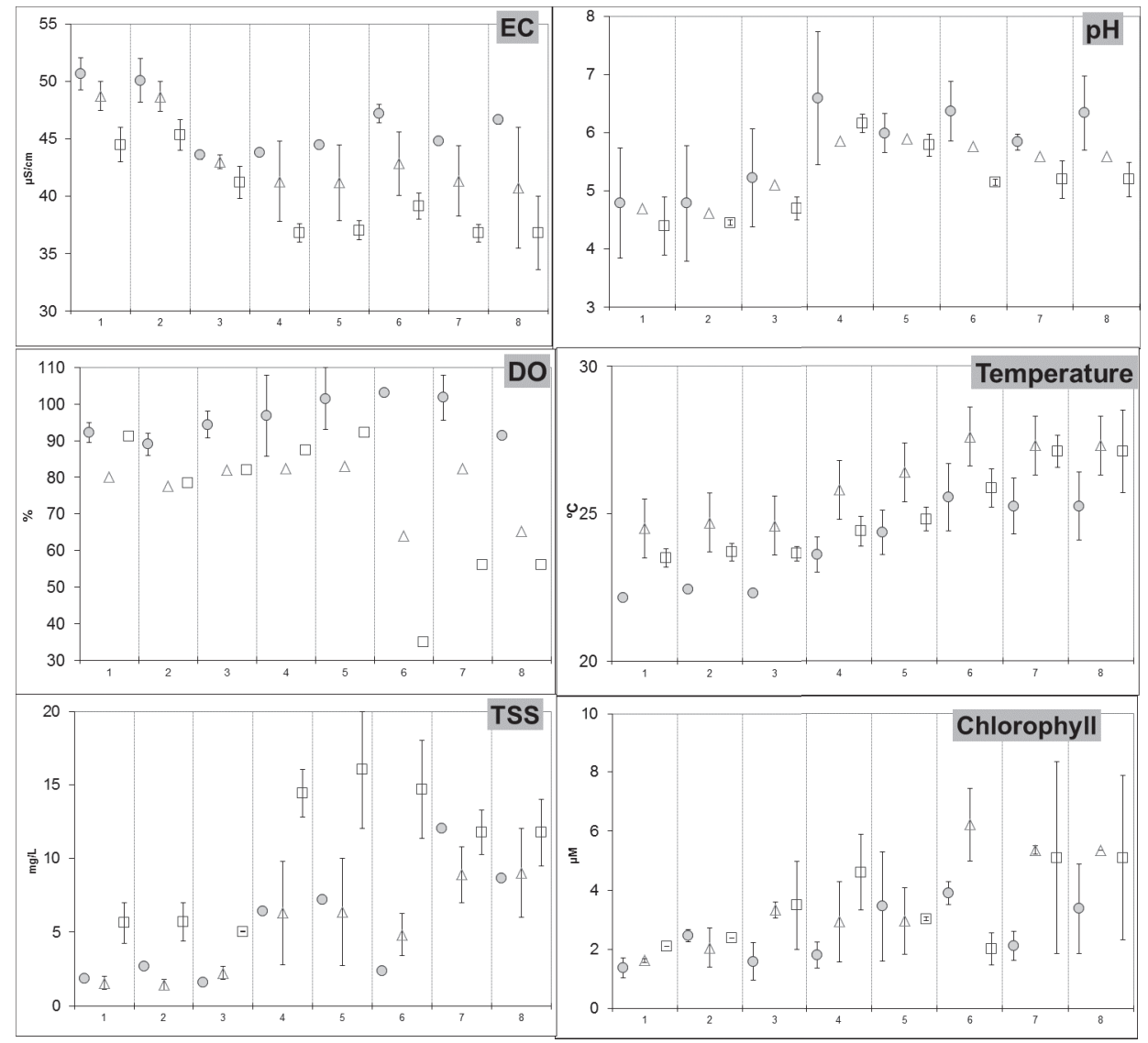

Figure 4 - Variation of electric conductivity (EC), $\mathrm{pH}$, dissolved oxygen saturation (OD), temperature, total suspended solids (TSS) and chlorophyll at the eight stations, related to dry (circles), intermediate (triangles) and wet (squares) periods. Averages and standard error for each sampling point.
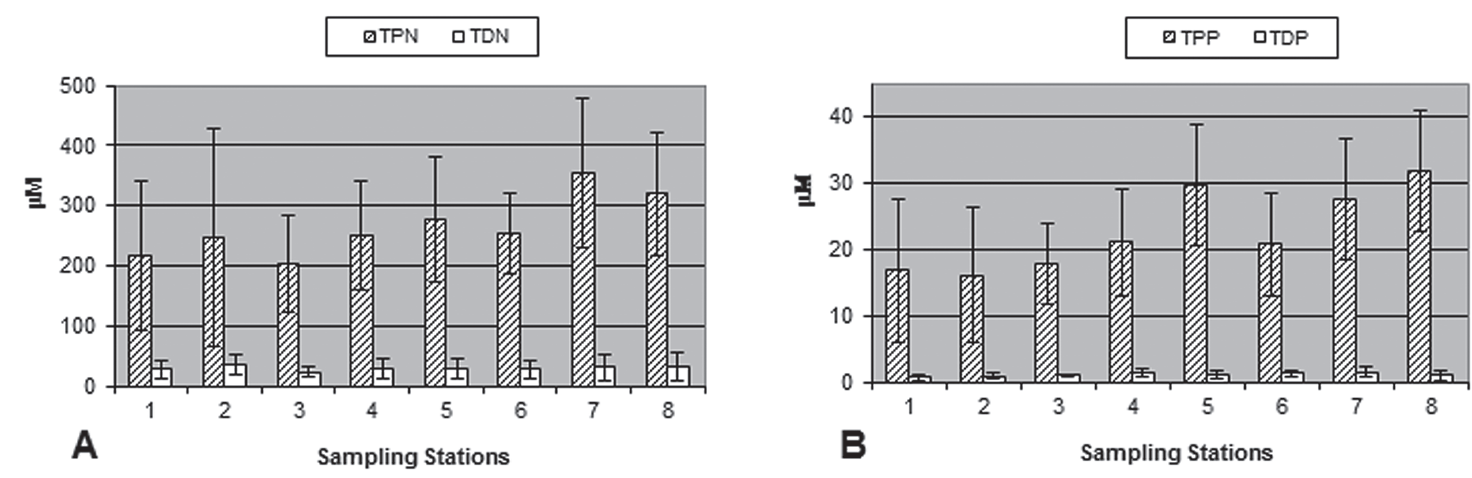

Figure 5 - Mean values and standard deviation of (A) Total particulate and dissolved Nitrogen; (B) Total particulate and dissolved Phosphorous.

points in relation to the patches of the medium and final points of the basin. The smaller width of the river and the shading provoked by the presence of the dense and conserved forest at the headwater points, determined the lower water temperatures of this patch. The higher vegetal coverage in the superior patch of the basin also controls the low $\mathrm{pH}$ values of this patch, since these points receive 
significant contribution of allochthonous organic matter, with the consequential formation of humic acids liberated during the decomposition process.

The higher TSS concentrations at the patches of the medium and final points of the basin reflect the progressive reduction of the vegetal coverage in these areas (Sator et al. 2007, Branco and Necchi Jr 1997, Marques et al. 2003). The spatial differences of the chlorophyll can be explained by the minor exposition to the sunlight at the headwater points. This variable shows a positive correlation with the temperature $\left(\mathrm{r}^{2}\right.$ $=0.82$ ). The chlorophyll and temperature values rise at the downstream points, where the water bodies appear with higher chute and, consequently, higher exposition to the sunlight, regardless of the higher TSS concentration at these points.

TN and TP do not present a clear spatial distinction, contrarily to their dissolved forms, principally the inorganic species, that reflect clearly the differences between the different studied sectors. The lowest nitrate concentrations were found at the headwaters, resulting of the riparian zone influence retaining the nitrate at the superior patch of the basin (Marques 2004). The contrary occurred with the phosphate, which had its lowest concentrations at the final patches of the basin. The strong affinity of the phosphorus with the particulate fraction (House 2003), favors the phosphate adsoption to the TSS, which also increases in this region. The higher DON percentuals at the headwaters are related to the decomposition of the organic matter originated in the Biological Reserve. In this patch, where the vegetation is dense, the allochthonous contributions are relatively larger in relation than those of the medium and final patches.

The DO concentrations and fecal coliforms did not present any distinction among the stations according to the test. Related to this last parameter, the absence of large population agglomerations in all the extension of the basin, is the main factor for the low concentrations.
The electric conductivity and the silicate presented a distinction of points 1 and 2 to sampling points 3 and 4 , reflecting the mineralogical differences between the granulites and the predominantly quartz sediments of the Barreiras Formation, which composes entirely the substrate of the sub-basin of the São Caetano Creek (Fig.1). At the other points the silicate concentrations were more elevated due to the soil use, with intense deforestation for the implantation of pastures or small plantations.

The ANOVA still points out at the influence of season in the temperature variation, the DO, the electric conductivity, the TSS and the nitrate and silicate concentrations. According to the TUKEY test, the 1st and 6th campaigns present significant differences compared to the 4th and 5th campaigns $(\mathrm{p}<0.05)$, showing a differenced pattern between dry and wet periods. The higher DO concentrations at the former are related with the minor load of allochthonous organic matter, which reduced the oxygen demand for decomposition (Rezende and Mazzoni 2005). Similar to the DO, the electric conductivity, the nitrate and the silicate concentrations present a clear distinction between campaigns, presenting always higher values during the dry period. The larger water volume in the wet season provoked a dilution of the dissolved elements, reducing the conductivity and the nitrate and silicate concentrations (Marques et al. 2003), maintaining concentrations distribution of the spatial pattern mentioned above. The TSS concentrations in the wet period campaigns were significantly larger in relation to dry periods, due to the superficial outflow of the rain waters provoking a larger soil matter contribution for the water bodies. For the TSS, the difference between dry and wet periods becomes still higher at the patches of the medium and final stations, where the forest has been retired, revealing the buffering capacity promoted by the maintenance of the original vegetal coverage. (Branco and Necchi Jr 1997, Marques et 

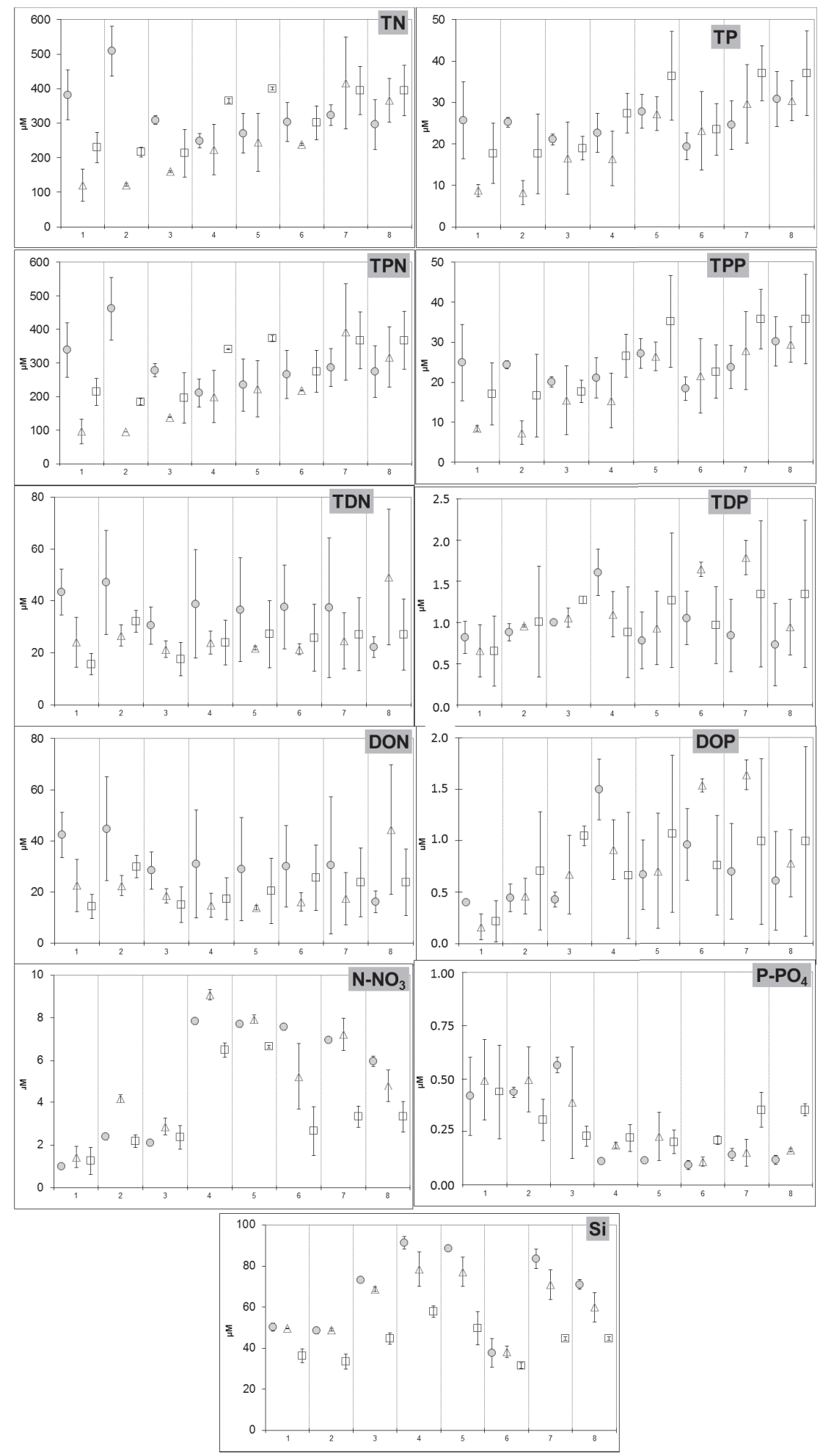

Figure 6 - Variations in total nitrogen concentrations - TN (A), total phosphorus - TP (B), total dissolved nitrogen - TDN (C), total dissolved phosphorus - TDP (D), nitrate (E), phosphate (F) and silicate (G) at the eight stations, related to dry (circles), intermediate (triangles) and wet (squares) periods. Averages and standard error for each sampling point. Nitrite and ammonia concentrations are not shown because they were very close to the detections limit. 
al. 2003, S.C.B. Sator et al., unpublished data).

The concentrations of total nitrogen (TN) and total phosphorus (TP) were not significant different between the dry and wet campaigns or between sampling stations. The nitrite and ammonia were always very close, or under the method detection limit, so the nitrate responds for the totality of the inorganic fraction of the DIN. The lowest nitrate concentrations $(0.6 \mu \mathrm{M})$ were found at the headwaters stations and the higher at the middle and final portions (up to 9.3 and $8.0 \mu \mathrm{M}$ respectively). Unlike nitrate, phosphate concentrations were higher at the headwater stations $(0.7 \mu \mathrm{M})$ and lower at the middle and final portions $(0.1 \mu \mathrm{M})$.

The concentrations of fecal coliforms did not present any spatial or seasonal distinction in the Rio da Serra Basin, with values oscillating between 78 and $690 \mathrm{CFU} / 100 \mathrm{~mL}$ (Fig. 7).

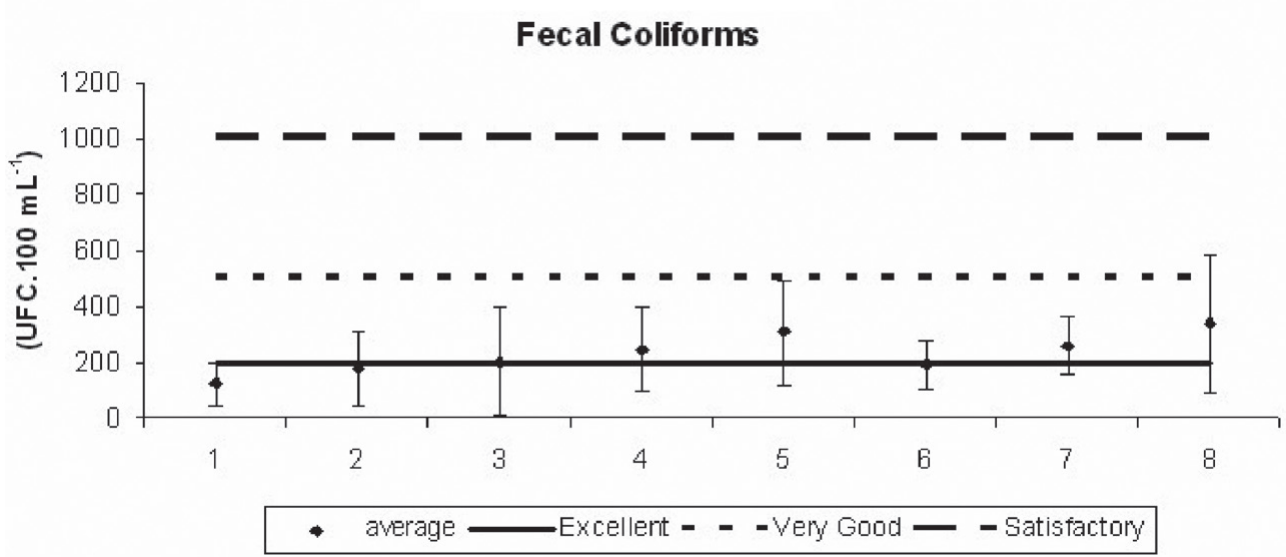

Figure 7 - Average values and standard deviation of the fecal coliforms concentrations for each sampling point at length of the Rio da Serra Basin. The lines limit the ranges established by the CONAMA 357/05 as Satisfactory, Very well and Excellent (Brasil 2005).

These low values are an obvious reflex of the absence of any significant population nucleus in the area, reinforcing the quasi pristine characteristics of this watershed. In these aspects it is interesting to compare the obtained results, with proposed values of trophic levels in rivers (Lamparelli 2004). According to this proposition, the Rio da Serra basin is classified as ultra-oligotrophic, with TP values inferior to 0.013 $\mathrm{mg} / \mathrm{L}$, which is expected, in view of the absence of significant sources of domestic organic effluents.

Two large wetlands exist in the Rio da Serra Basin: the first one separates points 5 and 7 (distant approximately $3 \mathrm{~km}$ one from another) on the Rio da Serra, originated in function of the BA 001 Highway construction, and the second one at point 6, near the mouth of the Serra Stream (Fig. 8).

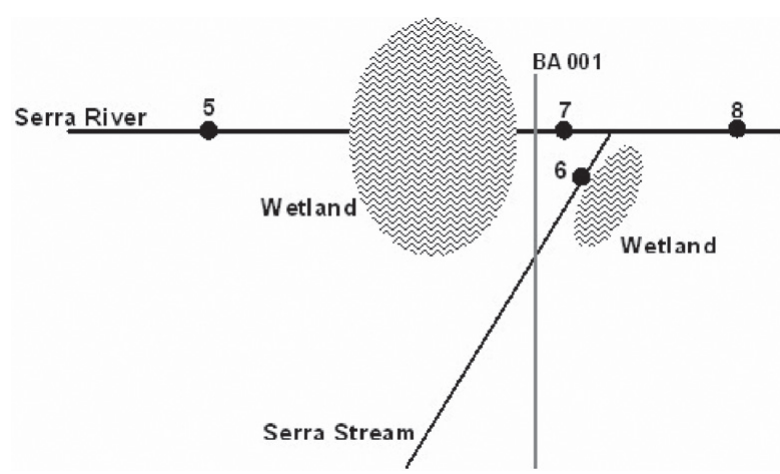

Figure 8 - Schematic drawing of a patch of the Rio da Serra Basin, with emphasis on the location of the wetlands at point 6 and between points 5 and 7 .

As stated by the literature (Esteves 1998, Tundisi and Tundisi 2008, Wetzel 1993) wetlands possess other differentiated biogeochemical dynamics than those present in the lotic bodies at which they are 
associated. In this research, an abrupt reduction of $\mathrm{pH}, \mathrm{DO}$ and nitrate was observed, besides of an increase in phosphate, in wet season campaigns, upstream and downstream of the areas subjected to wetting. In the dry period the fluvial waters run in defined banks, while during wet season they communicate with the flooded areas. The high productivity of the wetland areas induces hypoxia when the oxidative decomposition of the produced organic matter occurs, in this case represented by the increase of the acidity and reduction of the oxygen concentration (Junk et. al. 1989). Likewise, the congeniality of the denitrification process, characteristic of these environments, is manifested at those points. The reducing conditions of the water of the wetlands, create favorable conditions for the liberation of phosphorus from the sediments for the water column, being incorporated to the fluvial channel during the wet pulse (Junk et al. 1989), as detected in the Rio da Serra basin and in a study in similar areas of the Domain (Marques et al. 2003).

A concise discussion of the obtained data can be developed, interpreting the results of the PCA, represented in Figure 9. Using the results of all the variables analyzed in campaigns 4, 5 and 6, which do not present gaps referent to the physical-chemical data, and are representative of wet, intermediate and dry periods, a formation of three different groups can be observed. The first group evidences the spatial gradient of the basin and is associated to the horizontal axis. This group shows a combination of the headwater points at the two quadrants right of the graphic, differentiated from the points of the medium and final patches, determining a zoning in the fluvial hydrochemistry between a forested area and a deforested one, being, principally, impelled by DON and phosphate and negatively correlated with $\mathrm{pH}$ and nitrate.

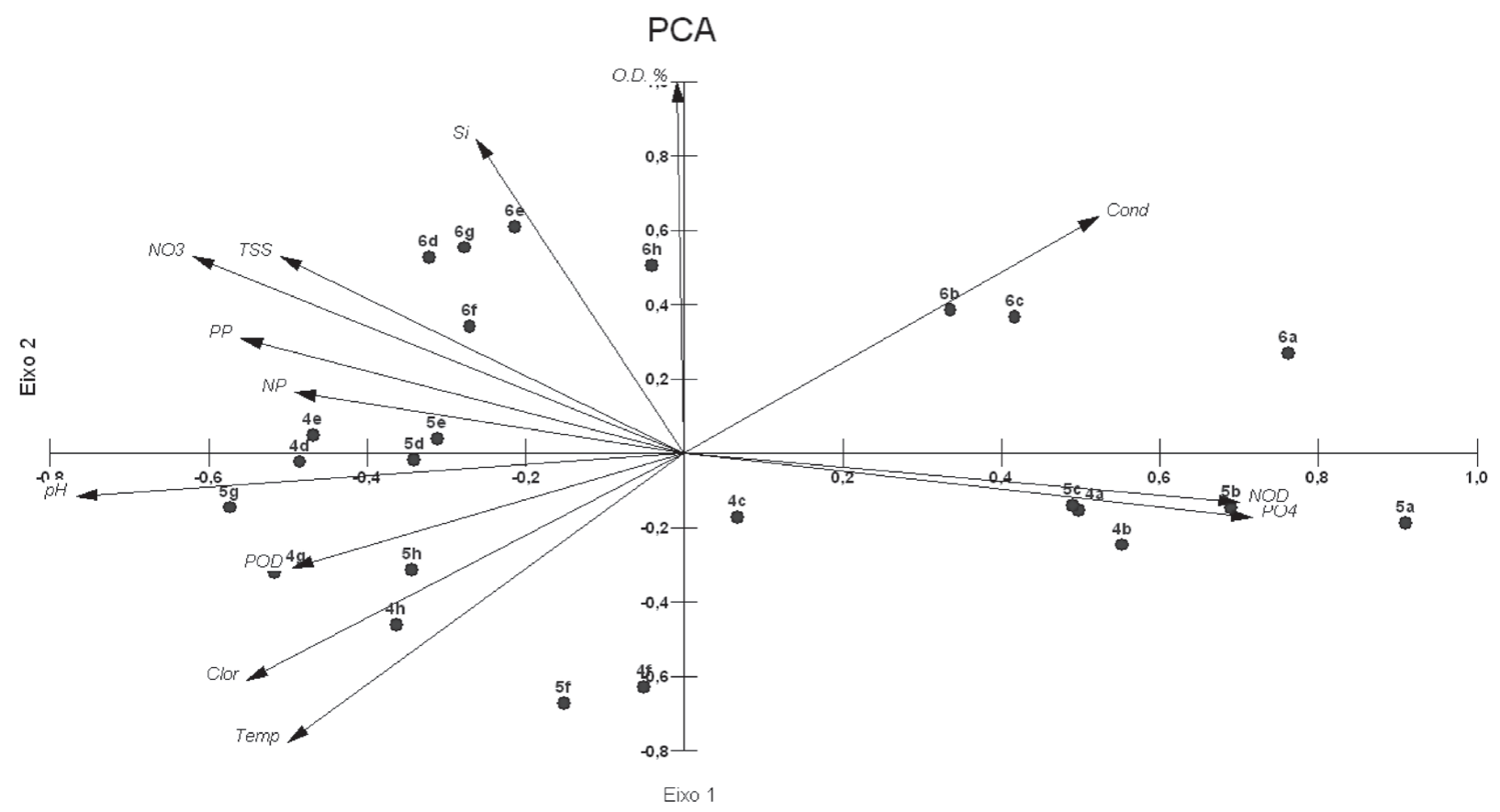

Vector scalina: 1.98

Figure 9 - Principal Component Analysis for the physical-chemical data, TSS, Chlorophyll, Nitrogen (PN, nitrate and DON), phosphorus (PP, phosphate and DOP) and silicate. The numbers 4, 5 and 6 represent the campaigns 4, 5 and 6 representative of wet, intermediate and dry periods respectively, and the letters from (a) to (h) represent the stations from 1 to 8 . 
The second group, associated to the vertical axis, groups stations 6 (points $6 \mathrm{a}$ and $6 \mathrm{~h}$ ) sampled at dry period, demonstrating that the base flow is the period with the highest definition of the spectral signature of the system, represented, principally by DO, silicate and conductivity, which presented more elevated values, for all the stations in this period. The temperature separates negatively the 6th campaign from the others, always lower in this campaign. The third group reflects the influence of the wetland, and appears in the distinction of the obtained distribution for point 6 between the dry period campaign (6f) and the others ( $4 \mathrm{f}$ and $5 \mathrm{f}$ ). These last ones were grouped influenced by the oxygen saturation (DO\%), taken that some peculiarities of this point provoke a large variation of the DO between campaigns, tending to hypoxia at wet season.

\section{CONCLUSION}

The base flow that characterizes the dry period was the one which provided a remarkable hydrochemical signature different from intermediate and wet periods when the signal is not well defined. Electric conductivity, DO, TSS, besides the nitrate, were the variables which most clearly felt the control exercised by season, in the behavior of the fluvial hydrochemistry of the studied area.

The differences in the spatial gradient of the watershed of the Rio da Serra could be observed by the separation between the acting processes at the headwater in relation to the medium and final patches, in function of the excellent preservation state upstream the basin. Thus, although the predominance of the particulate fraction of TP and $\mathrm{TN}$ in all stations, the speciation process of the dissolved forms, which sets the DON and the phosphate dominating at the headwaters and, the nitrate and DOP downstream, reveals a change induced by processes of biogeochemical speciation and cycling of these elements.

The existence of wetlands in the Rio da Serra basin was responsible for downstream fluvial hydrochemical changes, reduction of $\mathrm{pH}$, DO and nitrate besides the increase in phosphate concentrations, during the wet period, when the inundation pulse mixes the stagnated waters of these areas with running river waters.

\section{ACKNOWLEDGMENTS}

This research was partially financed by the Projeto Instituto do Milênio, Transferência de Materiais na Interface Continente-Oceano, Conselho Nacional de Desenvolvimento Científico e Tecnológico (Proc. CNPq No. 420.050/2005-1) and by the CTHIDRO Program. Rainfall data kindly provided by the climatology sector of the CEPLAC. Anonymous revisers deeply contribute to improve the final version.

\section{RESUMO}

A bacia hidrográfica do Rio da Serra tem suas cabeceiras situadas em remanescentes de mata ombrófila densa em excelente estado de preservação e pequenas propriedades rurais nos trechos médio e final. Tais características permitem o estudo da hidroquímica fluvial sob condições quase que totalmente sem interferência antrópica. Foram adotadas estações de coletas em locais representativos da bacia, e coletadas amostras durante os períodos de seca, intermediário e cheias. Os resultados obtidos foram: temperatura $\left(22,1-28,6^{\circ} \mathrm{C}\right)$; condutividade elétrica $(34$ $-52 \mu \mathrm{S} / \mathrm{cm})$; oxigênio dissolvido $(35-110 \%)$; $\mathrm{pH}(3,8-$ 7,7); TSS (1,1 - $20 \mathrm{mg} / \mathrm{L})$; clorofila-a (1,0 - 9,2 $\mu \mathrm{g} / \mathrm{L}) ; \mathrm{N}$ total $(74-580 \mu \mathrm{mol} / \mathrm{L}) ; \mathrm{N}$ particulado $(60-550 \mu \mathrm{mol} / \mathrm{L})$; N-NO3 (0,1 - 9,3 $\mu \mathrm{mol} / \mathrm{L})$; N orgânico dissolvido (4 -70 $\mu \mathrm{mol} / \mathrm{L}) ; \mathrm{P}$ total $(5,3-47 \mu \mathrm{mol} / \mathrm{L}) ; \mathrm{P}$ particulado $(4,4$ - $59 \mu \mathrm{mol} / \mathrm{L})$; P-PO4 (0,1 - 0,7 $\mu \mathrm{mol} / \mathrm{L}) ; \mathrm{P}$ orgânico dissolvido (0,01 - 2,0 $\mu \mathrm{mol} / \mathrm{L})$; silicato (30 -90 $\mu \mathrm{mol} / \mathrm{L})$; coliformes fecais $(80-700 \mathrm{UFC} / 100 \mathrm{~mL})$. Em termos sazonais oxigênio dissolvido, condutividade elétrica, nitrato e silicato, apresentaram maiores concentrações no período de seca e TSS no período de cheias. Diferenças no oxigênio dissolvido, temperatura, $\mathrm{pH}$ e nitrato foram detectadas nos locais sob influência de áreas alagadas. Ao longo da bacia os resultados evidenciaram a diferenciação 
entre as cabeceiras e as outras seções revelando o controle da hidroquímica fluvial pela área preservada, principalmente para $\mathrm{N}$ e $\mathrm{P}$ orgânicos dissolvidos e fosfato.

Palavras-chave: Ecologia de rios, nutrientes dissolvidos, reserva biológica, áreas alagadas.

\section{REFERENCES}

ALLAM JD. 1995. Stream ecology. Structure and fuction of running waters. $1^{\text {st }}$ ed., Chapman \& Hall. London.

APHA/AWWA. 1995. Standard Methods for the Examination of Water and Wastewater. APHA. Washington.

ARaÚJo M, ALGER K, Rocha R AND MESQUita CAB. 1998. A Mata Atlântica no Sul da Bahia. Série: Cadernos da Reserva da Bioesfera da Mata Atlântica (8). Conselho Nacional da Reserva da Biosfera da Mata Atlântica, São Paulo.

BRANCO LHZ AND NECCHI JR O. 1997. Variação longitudinal de parâmetros físicos e químicos em três rios pertencentes a diferentes bacias de drenagens na região noroeste do Estado de São Paulo. Acta Limnol Bras 9(1): 165-177.

BRASIL. 1976. Ministério das Minas e Energia. Departamento Nacional da Produção Mineral. Projeto Radam Brasil, Folha Salvador. Rio de Janeiro.

BRASIL. 2000. Sistema Nacional de Unidades de Conservação - SNUC. Lei $n^{\circ} 9985$ de 18 de julho de 2000. Diário Oficial da República Federativa do Brasil, Brasília.

BRASIL. 2005. Ministério do Meio Ambiente e da Amazônia Legal. Conselho Nacional do Meio Ambiente CONAMA. Resolução 357, de 17 de março de 2005. Diário Oficial da República Federativa do Brasil, Brasília.

CAmargo AFM, Ferreira RAR and Chiavetti A. 1996. Influence of physiography and human activity on limnological characteristics of lotic ecosystems of the south coast of São Paulo, Brazil. Acta Limnol Bras 8: 231-243.

CARMOUZE JP. 1994. O metabolismo dos ecossistemas aquáticos. Edgard Blücher, FAPESP, São Paulo.

Conama. Resolução 357, de 17 de março de 2005. Diário Oficial da República Federativa do Brasil, Brasília.

DePaula FCF AND Mozeto AA. 2001. Biogeochemical evolution of trace elements in pristine wathersed in the Brasilian, Southeastern coastal region. Appl Geochem 16: 1139-1151.

EsteVes FA. 1998. Fundamentos de Limnologia. $2^{\mathrm{a}}$ ed., Rio de Janeiro: Interciência.

GIBBS JR. 1970. Mechanisms controlling world water chemistry. Science 170: 1088-1090.

Grasshoff K, EhrardT M AND KrEMLING K. 1983. Methods of seawater analysis. Wheinhein: Verlag Chermie.

HAMmer Ø, HARPer DAT AND RYAN PD. 2001. Past: paleontological statistics software package for education and data analysis. Palaeontologia Electronica.

HoRne HJ AND GOLDMAN CR. 1994. Limnology. McGrawHill, New York.
HousE WA. 2003. Geochemical cycling of phosphorus in rivers. Appl Geochem 18: 739-748.

HYNES HBN. 1975. Edgardo Baldi Memorial Lecture: The stream and is valley. Verh Internat Verein Limnol 19: 1-15.

JunK WJ, BAYLEY PB AND SPARKS RE. 1989. The flood-pulse concept in river-floodplain systems. In: DODGE DP (Ed), Proceedings of the International Large River Symposium Canadian. Fisheries and Aquatic Sciences. Special Publication 106: 110-127.

KRUSCHE AV ET AL. 2005. Efeitos das mudanças do uso da terra na biogeoquímica dos corpos d'água da Bacia do Rio Ji-Paraná, Rondônia. Acta Amazon 35(2): 197-205.

LAMPARELLI MC. 2004. Graus de trofia em corpos d'água do Estado de São Paulo: Avaliação dos métodos de monitoramento. Tese de Doutorado em ciências. Instituto de Biociências, Universidade de São Paulo, São Paulo, $237 \mathrm{p}$.

Landau EC, Moura RT, Pinto LPS, Fonseca GAB and Alger K. 2003. Corredor de Biodiversidade da Mata Atlântica do Sul da Bahia. Publicação em CD-ROM, Ilhéus, IESB/CI/CABS/UFMG/UNICAMP.

LONRANDI R AND CANÇADO CJ. 2005. Parâmetros físicos para gerenciamento de Bacias Hidrográficas. In: Conceitos de Bacias Hidrográficas, Schiavetti A and Camargo A FM. EDITUS. Ilhéus, Cap. 2.

LOWE-MCCONNELL RHL. 1987. Ecological Studies in Tropical Fish communities. Combridge, University Press.

MAB / UNESCO. 1972. Man and Biosphere Program. Disponível em: http://portal.unesco.org/science/en/ ev.php-url_id=6393\&url_do=do_topic\&url_section $=201$. html. Acesso em: 05/out/2009.

MARQUES PHC. 2004. Integração entre Ecologia de Bacias Hidrográficas e Educação Ambiental para a conservação dos rios da Serra do Mar no Estado do Paraná. Tese de Doutorado em Ecologia e Recursos Naturais, Universidade Federal de São Carlos, São Carlos, 189 p.

Marques PHC, Oliveira HT AND Machado EC. 2003. Liminological study of Piraquara River (Upper Iguaçu Basin): Spatiotemporal variation of physical and chemical variables and Watershed Zoning. Braz Arch Biol Techn 46(3): 383-394.

Martinelli La, Silva AM, Camargo PB, Moretti LR, Tomazelli AC, SiLVa DML, Fischer EG, Sonoda KC AND SALOMÃo MSMB. 2002. Levantamento das cargas orgânicas lançadas nos rios do Estado de São Paulo. Biota Neotrop 2: 1-17.

Meyers N, Mittermeier RA, Mittermeier CG, FonseCa GAB AND Kents J. 2000. Biodiversity Hotspots for Conservation Priorities. Nature 403: 853-858.

NeCCHI JR O, BRANCO LHZ AND BRANCO CCZ. 2000. Características limnológicas da Bacia do Alto Rio São Francisco. Parque Nacional da Serra da Canastra, MG. Acta limonol Bras 12(1): 11-22.

Parsons TR, Maita Y and Lalli CM. 1984. A Manual of Chemical and Biological Methods for Seawater Analisys. Pergamon Press, $173 \mathrm{p}$. 
PETTS GE. 2000. A perspective on the abiotic processes sustaining the ecological integrity of running waters. Hidrobyologia 422/423: 15-27.

REZENDE CF AND MAZZONI R. 2005. Seasonal variation in the input of allochthonous matter in na Atlantic Rain Forest estream, Ilha Grande - RJ. Acta Limnol Bras 17(2): 167175 .

SATOR SCB, Walcchiolz F AND Pereira Filho W. 2007. Relação das variáveis TSS e transparência da água com o uso da terra na área de captação das sub-bacias do Reservatório Rodolfo Costa e Silva - RS. In: Simpósio Brasileiro de Sensoriamento Remoto. Florianópolis, Anais. INPE.

SMith WS AND PETRERE JR M. 2000. Caracterização limnológica da Bacia de drenagem do Rio Sorocaba. Acta limnol Bras 12(1): 15-27.

S.O.S. MATA ATLÂNTICA/INPE. 2009. Atlas dos Remanescentes Florestais da Mata Atlântica, Período 2005-2008. Disponível em: http://mapas.sosma.org.br/dados/. Acesso em: 05/10/2009.
STRICKLAND JDH AND PARSONS TR. 1972. A Pratical Handbook of Seawater Analysis. Bull Fish Res Board Can 167: 1-205.

TUNDISI JG AND TUNDISI TM. 2008. Limnologia. $1^{\mathrm{a}}$ ed., Oficina de Textos, São Paulo, 580 p.

VANNOTE LR, Minshall GW, Cummins KW, SEDEL JR AND Cushing CE. 1980. The River Continuum Concept. Can J. Fish Aquat Sci 37(1): 130-137.

WARD JV AND STANFORD JA. 1983. The serial discontinuity concept in lotic ecosystems. In: Dynamic of lotic ecosystems. Ann, Arbor. Fontaine TD and Barthel SMEDS. Science. Michigan, p. 347-356.

WAYT THOMAS WM, CARVALHO AMV, AMORIM AMA GARRISON J AND ARBELÀEZ AL. 1998. Plant Endemism in Two Forests in Southern Bahia, Brazil. Biodivers Conserv 7: 311-322.

Wetzel RG. 1993. Limnologia. $2^{\text {a }}$ ed., Lisboa. Fundação Calouste Gulbenkiam.

ZAR JH. 1999. Bioestatistical Analysis. $4^{\text {th }}$ ed., New Jersey, Pretence-Hall. 